\title{
Retraction note: Antimicrobial and Antifungal Effects of Green Tea Extracts against Microorganisms Causing Vaginitis
}

\author{
Yong-Wan Kim, Heung Jae Chun, In-Wook Kim, Hai-Bo Liu, and Woong Shick Ahn
}

Published Online June 30, 2014

(C) KoSFoST and Springer 2014

Retraction note to: Food Sci. Biotechnol. 22(3): 713-719 (2013)

DOI 10.1007/s10068-013-0136-3

This article has been retracted upon request of the Committee on Publicing Ethics (COPE) of Korean Society of Food Science and Technology, since over 70\% similarity including 'Results and Discussion' in this article was found with an article published in Journal of Woman's Medicine (2008), titled "Antimicrobial and antifungal effects of a green tea extract against vaginal pathogens".

The online version of the original article can be found under doi: 10.1007/s10068-013-0136-3

Woong Shick Ahn $(\triangle)$

Department of Obstetrics and Gynecology, College of Medicine, The Catholic University of Korea, Seoul 137-701, Korea

Tel: +82-2-2258-7489; Fax: +82-2-533-4120

E-mail: ahnlab@catholic.ac.kr

Yong-Wan Kim, In-Wook Kim, Hai-Bo Liu

Catholic Research Institute of Medical Science, The Catholic University of Korea, Seoul 137-701, Korea

Heung Jae Chun

Institute of Cell and Tissue Engineering, The Catholic University of Korea, Seoul 137-701, Korea 